\title{
POPE GREGORY THE GREAT'S ARGUMENTS AGAINST THE ECUMENICAL TITLE OF THE PATRIARCH OF CONSTANTINOPLE: ANALYSIS OF THE LETTERS FROM 595
}

\author{
Aleksei V. Migalnikov \\ St. Tikhon's Orthodox University, Moscow, Russian Federation
}

\begin{abstract}
Introduction. At the end of the sixth century a dispute broke out between the popes and the patriarchs of Constantinople - first of all, between pope Gregory I the Great (590-604) and patriarch John IV the Faster (582-595) - over the epithet "Ecumenical", which appeared in the title of John of Constantinople. This dispute is quite widely represented in the scientific literature, but since researchers almost always pay attention to this topic in general, their papers often miss many nuances contained in the texts of the letters of pope Gregory. Methods. This article attempts a detailed analysis of the first series of letters of pope Gregory dedicated to the dispute and related to 595. These are letters to emperor Maurice (582-602), empress Constantina, the patriarch John IV of Constantinople, and the papal apocrisiary in Constantinople, deacon Sabinianus. The purpose of this study is to reconstruct pope Gregory's argumentation system against the use of the Ecumenical title. Analysis. The author identifies several types of arguments that pope Gregory puts forward in his polemic against the title: canonical, biblical, dogmatic, ecclesiastical, political, pastoral and ascetic. Results. The article shows, on the one hand, what the letters have in common, and on the other, how the arguments of the pope vary depending on the recipient. Generally, pope Gregory expresses a sharply negative attitude to the title, and many researchers tend to see this fact as a contradiction to the concept of papal primacy, as it developed in a later period. Basing on the significant differences in argumentation between the letters to the emperor, the empress and the patriarch John with the same purpose of all the messages - the article makes a conclusion about the care with which pope Gregory selects arguments. This can serve as one of the indirect indicators of the high importance of the dispute over the Ecumenical title for him, and also characterizes his perception of the idea of Church power in general.

Key words: the Ecumenical title, papal primacy, the Universal Church, pope Gregory the Great, patriarch of Constantinople John the Faster, emperor Mauricius, empress Constantina, pope Sabinianus.

Citation. Migalnikov A.V. Pope Gregory the Great's Arguments Against the Ecumenical Title of the Patriarch of Constantinople: Analysis of the Letters from 595. Vestnik Volgogradskogo gosudarstvennogo universiteta. Seriya 4. Istoriya. Regionovedenie. Mezhdunarodnye otnosheniya [Science Journal of Volgograd State University. History. Area Studies. International Relations], 2021, vol. 26, no. 6, pp. 290-303. (in Russian). DOI: https://doi.org/10.15688/jvolsu4.2021.6.21
\end{abstract}

\section{АРГУМЕНТАЦИЯ ПАПЫ ГРИГОРИЯ ВЕЛИКОГО ПРОТИВ ТИТУЛА «ВСЕЛЕНСКИЙ» КОНСТАНТИНОПОЛЬСКИХ ПАТРИАРХОВ: АНАЛИЗ ПИСЕМ 595 ГОДА}

\section{Алексей Владимирович Мигальников}

Православный Свято-Тихоновский гуманитарный университет, г. Москва, Российская Федерация

Аннотация. В конце VI в. между римскими папами и константинопольскими патриархами - прежде всего между папой Григорием Великим (590-604) и патриархом Иоанном Постником (582-595) - разгорается спор об эпитете «вселенский», фигурировавшем в титуловании Иоанна Константинопольского. Данный спор достаточно широко представлен в научной литературе, но поскольку исследователи почти всегда уделя- 
ют внимание этой теме в целом, в их работах зачастую теряются многочисленные нюансы, содержащиеся в текстах посланий папы Григория. В настоящей статье предпринята попытка детального анализа первой серии писем папы Григория, посвященных спору и относящихся к 595 г. Это письма императору Маврикию (582-602), императрице Константине, Константинопольскому патриарху Иоанну Постнику и папскому апокрисиарию в Константинополе, диакону Сабиниану. Целью данного исследования является реконструкция системы аргументации папы Григория, направленной против использования титула «вселенский». Автор выделяет несколько типов аргументов, которые папа Григорий выдвигает в своей полемике против титула: канонические, библейские, догматические, церковно-политические, политические, пастырские, аскетические. В статье показано, с одной стороны, что между письмами есть общего, и с другой, как аргументы папы варьируются в зависимости от адресата. В целом папа Григорий выражает резко негативное отношение к титулу, в чем многие исследователи склонны усматривать противоречие концепции папского примата, развившейся в более поздний период. Исходя из значительных различий в аргументации между посланиями императору, императрице и патриарху Иоанну - при единстве цели посланий, - делается вывод о тщательности, с которой папа Григорий подбирает аргументы, что может служить одним из косвенных указаний на высокую важность для него спора о титуле «вселенский», а также характеризует восприятие им идеи церковной власти в целом.

Ключевые слова: титул «вселенский», папский примат, Вселенская Церковь, папа Григорий Великий, патриарх Константинопольский Иоанн Постник, император Маврикий, императрица Константина, папа Сабиниан.

Цитирование. Мигальников А. В. Аргументация папы Григория Великого против титула «вселенский» константинопольских патриархов: анализ писем 595 года // Вестник Волгоградского государственного университета. Серия 4, История. Регионоведение. Международные отношения. - 2021. - Т. 26, № 6. - С. 290-303. DOI: https://doi.org/10.15688/jvolsu4.2021.6.21

Введение. Григорий Великий (590-604) является одним из наиболее выдающихся римских пап поздней античности [6, с. 9-41; 10 , p. 629-633; 16, S. 306-514; 17, p. 658-674; 23; 31, S. 294-308, 364-367; 34; 35, p. 65-68; 37 , p. 1-16; 38; 40]. Именно ему было суждено восстановить авторитет римской кафедры, переживавшей сравнительный упадок в результате возвращения Италии в лоно Римской империи при Юстиниане и жесткой политики последнего, направленной на встраивание Римской Церкви в церковно-административную систему государства [25, p. 71-84; 26 , S. 35-53, 217-218; 32, S. 348-403; 37, p. 83-96; 45, p. 139-161]. Понтификат Григория I был отмечен целым рядом крупных церковно-политических свершений и проходил на фоне важных событий, связанных с изменением политического ландшафта Италии в результате вторжения лангобардов [8, p. 91-101; 12, p. 231-284; 13, p. 13-21; 16, S. 471-486; 21 , p. $158-186 ; 22$, p. $3-42 ; 43 ; 45$, p. 162-180]. Письменное наследие Григория Великого по своему объему и значению является, пожалуй, беспрецедентным для истории папства первого тысячелетия. Одно собрание его посланий, сохранившихся в составе регистра, насчитывает свыше 800 единиц [33, р. 70-81; 44].
Григорий Великий продолжил традиционную для папства поздней античности политику утверждения собственного первенства в том, что по римской терминологии называлось «Вселенской Церковью» (ecclesia universalis). Как следствие, этот папа жестко отстаивал то, что он считал неотъемлемыми правами римской кафедры, и старался распространить влияние последней даже на самые отдаленные уголки от Британии до Сирии и Аравии [6, с. $153-166 ; 10$, р. 629-633; 16, S. 505-510; 17 , p. $671-673 ; 41$, p. 321-341; 42, p. 926-931; 49 , p. 32-44]. Именно в рамках этой деятельности по отстаиванию прав и привилегий римского престола Григорий неожиданно инициировал спор о «вселенском» титуле Константинопольского патриарха, являвшийся частью более широкого контекста отношений римского епископа с Востоком [9, р. 184-214; 10, p. $629-633 ; 14 ; 15$, p. 114-120; 16, S. 505-510; 17 ,p. 671-673; 22, p. 59-159; 27, p. 1-41; 30; 39, S. 79-95; 41; 42, p. 931-936, 942-958].

Методы. Исследователи жизни и творчества Григория Великого почти всегда уделяли внимание этому спору. Ему посвящены как отдельные, более или менее пространные отрывки общих работ [6, с. 203-222; 9, p. 204211 ; 10 , p. $630-631 ; 15$, p. $114-120$; 16, S. 452- 


\section{ВИЗАНТИЙСКОЕ ПРАВОСЛАВИЕ}

$463 ; 17$, p. 668-670; 22, p. 201-228; 26, S. $132-$ 137; 28, S. 99-110; 37, p. 91-96; 39, S. 324-329; 42, S. 945-948], так и специальные статьи [19; $29 ; 30$, p. 278-283; 36; 48; 51]. Тем не менее, следует признать, что практически во всех случаях исследователи уделяют внимание этому спору в целом, давая характеристику всей совокупности посланий Григория I, которые так или иначе его касаются. При таком подходе не только в значительной мере теряются многочисленные нюансы, содержащиеся в текстах посланий, но подчас вовсе оказывается неясным, как именно папа обосновывал свою позицию. В силу этого на основании исследовательской литературы зачастую невозможно в деталях проследить аргументацию Григория, а также контекст, в котором появляется та или иная серия посланий. Чтобы восполнить этот пробел, в настоящей статье мы поставили себе задачей посредством применения историко-критического метода провести подробный анализ серии из четырех писем июня 595 г., которые, собственно, и положили начало упомянутому спору ${ }^{1}$. Эти письма содержат особую, свойственную именно начальному периоду спора систему аргументации, которая впоследствии подверглась развитию и определенной модификации, по-видимому, под влиянием контраргументов корреспондентов и оппонентов папы $^{2}$. Нашей целью при этом будет выяснение системы аргументации папы Григория, посредством которой он намеревался убедить своих адресатов в неправомочности употребления Константинопольским патриархом титула «вселенский» ${ }^{3}$.

Анализ. В июне 595 г. папа Григорий впервые рассылает серию писем, в которых осуждает использование Константинопольским патриархом титула «вселенский». Адресатами папских писем являются император Маврикий, императрица, константинопольский патриарх Иоанн IV Постник (582-595) [5], а также респонсалий (или апокрисиарий - доверенное лицо) папы в Константинополе, диакон Сабиниан, впоследствии преемник Григория на папском престоле [24; 35, р. $68 ; 52$, p. 700-711]. Общая декларируемая цель всех четырех писем одна: папа желает, чтобы патриарх Иоанн прекратил использование титула. Однако тезисы и аргументация, к которой прибегает Григорий в обоснование неуместности использования титула, разнятся от одного письма к другому.

Одной из главных забот папы, по его словам, является благополучное правление императора Маврикия и процветание государства ${ }^{4}$. Во вступлении первого послания, адресованного самому императору, Григорий высказывается практически в духе юстиниановой концепции «симфонии»: «Благочестивейший и от Бога поставленный государь наш среди прочих забот и августейших тягостей, сохраняя правильность духовного усердия (conservanda rectitudine studii spiritalis), также бдит (invigilat) и в отношении священнической любви (sacerdotali caritati), очевидным образом благочестиво и правдиво полагая, что никто не может правильно управлять земным, если не будет уметь (nisi noverit) распоряжаться (tractare) божественным, и что мир государства (reipublicae) зависит от мира Вселенской Церкви. Ведь какая, о тишайший господин, человеческая сила и вообще всякая мощь плотского плеча (досл. «предплечья» - brachii) дерзнула бы (praesumeret) воздвигнуть нечестивые руки против вершины Вашей христианнейшей власти (imperii), если бы согласный со священниками разум молился за Вас, как полагается и по достоинству, своему Спасителю?» [46, p. 308.2-11]. Папа тем самым одобряет прежнее внимание императора к церковным делам и утверждает, что этим император обеспечивает долголетие своему царствованию.

Недолжное исполнение священнического долга приводит, по мнению Григория, к тому, что силы врагов империи возрастают: «Но пока мы покидаем то, что подобает нам, и помышляем о том, что не подобает, наши грехи мы соединяем с варварскими силами, а вина наша, которая отягощает силы государства, оттачивает мечи врагов» [46, p. 308.14-16]. Император располагает возможностью образумить священников и обратить их к исполнению их обязанностей: «По каковой причине в высшей степени предусмотрительно благочестивейший государь ради усмирения военных потрясений добивается мира Церкви, а также изволит склонять сердца священников к его упрочению» [46, p. 308.25-309.28]. 
Далее Григорий обозначает причину, грозящую крушением государству: «Поскольку это дело не мое, но Бога, поскольку не я один, но вся Церковь сотрясается, поскольку благочестивые законы, священный собор, поскольку даже сами заповеди Господа нашего Иисуса Христа сотрясаются измышлением некоего надменного и помпезного выражения, да рассечет благочестивейший господин пораненное место и упорствующую болезнь свяжет узами своего царственного распоряжения (augustae vinculis auctoritatis)» [46, p. 309.30-35].

Таким образом, целью написания письма императору является попытка Григория привлечь Маврикия в качестве союзника в инициируемом папой споре по поводу уже ставшего традиционным титула Константинопольского патриарха ${ }^{5}$. Папа желает добиться от императора, чтобы тот либо провел предварительное расследование, либо напрямую склонил патриарха Иоанна к отказу от титула [46, p. 311.101-104].

Императрицу Григорий просит, в свою очередь, о том, чтобы она «не попускала ничьему лицемерию преобладать над истиной» $[46$, p. 314.13]: каким именно образом императрица должна это сделать, папа не уточняет. Вероятно, для него было желательным, чтобы она оказала влияние на своего супруга: Григорию явно кажется несправедливым то, что император сделал ему «некое печальное указание, которое не того обличало, кто поступил надменно, но скорее стремилось отвратить от моего намерения меня [самого]» $\left[46\right.$, p. 315.33-35] ${ }^{6}$.

Мотивация в письме императрице получает новый оттенок - благополучие императорской семьи: папа говорит о «сокровищах вечного воздаяния», которые императрица получит для себя, своей семьи и отечества делом «исполнения истины» и «благоволения справедливости» [46, р. 314.3-4, 315.20-25]. Григорий отсылает ее к тому, что «родители [императорской четы], прежние принцепсы, искали благоволения апостола Петра» [46, p. 316.61-62] ${ }^{7}$. Очевидным образом, для папы Григория угождение апостолу означает поддержку позиции римского престола.

В письме же патриарху Иоанну звучание получает другой мотив: титул является про- явлением лести, которой патриарха окружили его приближенные, иными словами, патриарх Иоанн был ими обманут. Соответственно, Григорий просит Иоанна не соглашаться с теми, кто предлагает ему такой титул [46, p. 330.28-31, 332.96-100]. Он хочет «с неким уважением подтолкнуть [патриарха Иоанна] к стыду» [46, p. 330.23-25]. Смирение же патриарха в вопросе о титуле поможет восстановить нарушенный церковный мир: «Всем сердцем возлюби смирение, посредством которого способно сохраняться согласие всех братьев и единство святой Вселенской Церкви» [46, p. 331.43-45].

Письмо диакону Сабиниану заметно отличается от трех остальных писем этой серии как по форме (оно гораздо короче других), так и по содержанию. Оно не содержит каких-либо аргументов против титула «вселенский». Причины этого представляются достаточно ясными: это уже не первое послание, адресованное Сабиниану в контексте спора о титуле [46, p. 338.32-33], и потому тот был очевидным образом в курсе папской позиции, которую он должен был отстаивать в Константинополе. Григорий приказывает Сабиниану передать вышеупомянутое письмо, адресованное патриарху Иоанну, а также повторно запрещает ему появляться вместе с патриархом на официальных церемониях [46, p. 338.3233]. Такая мера должна была, по мысли Григория, «с неким уважением подтолкнуть [Иоанна] ко стыду (sub quadam verecundiae reverentia pulsarem)» $[46$, p. 330.22-25].

Позииия папы по поводу титула. Несмотря на то, что титул «вселенский» у Константинопольского патриарха впервые фиксируется в 518 г. [4, с. 40; 19, p. 602; 29, S. 568], Григорий подает это дело как новое и неслыханное [46, p. 309.58, 315.29-30], причем берущее начало именно со вступления на патриарший престол Константинополя Иоанна Постника (582-595). Обращаясь к последнему, папа говорит: «В то время, когда Ваше братство было возведено в священническое звание, помнит оно, какое застало оно мир и согласие Церквей. Но уж не знаю, из-за какого дерзновения или какого надмения оно попыталось присвоить себе новоявленное наименование, отчего сердца многих братьев могли бы войти в соблазн» [46, p. 329.2-6]. 


\section{ВИЗАНТИЙСКОЕ ПРАВОСЛАВИЕ}

Отношение папы Григория к титулу «вселенский» тем самым резко негативное. Он называет его «неслыханным и нечестивым именем» [46, p. 309.58], «негодным и надменным» [46, p. 330.15], «ошибочным именем» (erroris nomen) [46, p. 330.29-30], «гордым и глупым» [46, p. 330.41], «извращенным» [46, p. 331.55], «преступным» [46, p. 338.31]. Принятие патриархом титула - это «отвратительное и нечестивое надмение» [46, p. 330.25], а согласие с ним Григорий приравнивает к потере веры [46, р. 338.31-32].

Аргументация против титула. Представляется возможным выделить несколько типов аргументов, с которые папа Григорий использует в своей полемике:

- Канонические и библейские аргумен$m b l$ : титул противоречит Евангелию, церковным канонам и традиции.

- Догматические: титул противоречит церковному учению о сущности Церкви.

- Церковно-политические: титул нарушает церковный мир и единство, повышает опасность распространения ереси.

- Политические: скандал из-за титула представляет опасность для благополучия государства и императорской семьи.

- Пастырские: принятие титула не соответствует задачам священнического служения.

- Аскетические: титул является заблуждением, греховной ошибкой патриарха Иоанна, уподобляет его антихристу, представляет опасность для его спасения.

В каждом из писем присутствует вся или почти вся палитра аргументов, однако в каждом акцент сделан на аргументах одного-двух типов. В письме к императору папа Григорий чаще приводит политические и церковно-политические аргументы, указывая на опасность скандала для благополучия государства. В письме к императрице папа апеллирует к ее чувству справедливости и за ее участие сулит ей помощь апостола Петра. Наконец, патриарха Иоанна Григорий преимущественно убеждает пастырскими и аскетическими доводами - это письмо самое пространное, почти в 2 раза длиннее писем императору и императрице.

Указанные типы аргументов будут ниже рассмотрены нами подробнее.

Канонические и библейские аргумен$m b l$. Папа Григорий пишет императору о том, что патриарх Иоанн присваивает себе титул «вопреки евангельским определениям (statuta evangelica), вопреки постановлениям канонов (canonum decreta)» [46, p. 310.62-63]. Для него данный тезис, по-видимому, является самоочевидным и он не раскрывает, каким именно «определениям и канонам» противоречит использование Константинопольским патриархом титула «вселенский».

По мысли папы Григория, принятие титула не имеет позитивных аналогов в церковной традиции. Императору папа приводит пример апостола Петра, который, будучи одним из наиболее авторитетных для Римской и всех прочих церквей святым, все же не принимал подобного наименования: «Вот [апостол Петр] ключи Царства Небесного принимает, власть (potestas) вязать и решить ему дается, забота о всей церкви и главенство (principatus) на него возлагаются, однако же не зовется он вселенским апостолом (universalis apostolus)! А муж святейший и сосвященник мой Иоанн пытается назваться вселенским епископом (universalis episcopus)!» [9, p. 207; 15, p. 117; 19 , p. 609; 46, p. 309.48-52].

Не только апостол Петр, но и никто из святых когда-либо в истории не называл себя так [46, р. 332.83-86]. В частности, Григорий приводит пример папы Льва Великого (440461). В письме императору он представляет дело так, что в 451 г. на Халкидонском соборе титул «вселенский» был предложен участниками собора папе Льву, но тот отказался: «В самом же деле, [наименование "вселенским”] было преподнесено чтимым Халкидонским собором римскому понтифику ради чести блаженного Петра, главы апостолов (apostolorum principis). Однако никто из них (видимо, имеются ввиду папа Лев и его преемники - A.M.) никогда не соглашался использовать это исключительное наименование (singularitatis nomine), дабы в то время, как одному давалось нечто частное, все священники не лишались причитающейся чести. Так отчего же, стало быть, мы не добиваемся этого даже преподнесенного названия, а тот притязает его присвоить даже не преподнесенное?» [46, p. 310.77-83]. В письме патриарху Иоанну папа приводит тот же самый аргумент: «Разве, как Ваше братство знает, досточтимый Халкидонский собор предстояте- 
лей этого апостольского престола, которому я служу по устроению Божию, не назвал “вселенскими", оказав [им] эту честь? Однако никто и никогда не пожелал называться таким словом» [46, p. 332.89-92].

В приведенных выше утверждениях папа Григорий делает умышленный или неумышленный подлог, потому что лишь с очень большой натяжкой и многими оговорками можно утверждать, что титул был «преподнесен чтимым Халкидонским собором римскому понтифику». Фактически же он был применен к римскому епископу только в челобитных, поданных на имя папы Льва противниками Ди-

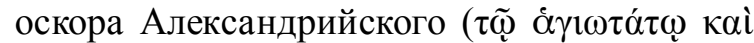

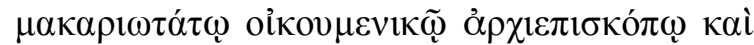
$\left.\pi \alpha \tau \rho \dot{\alpha} \rho \chi \eta \tau \tilde{\eta} \varsigma \mu \varepsilon \gamma \alpha \dot{\lambda} \lambda \varsigma^{~}{ }^{\circ} \mathrm{P} \omega \dot{\mu \eta} \varsigma\right)$ : однако такой прецедент едва ли можно квалифицировать как его соборное признание за римским епископом. Между тем в официальных речах и подписях папских представителей на Халкидонском соборе Лев неоднократно назывался «universalis ecclesiae papa urbis Romae», каковой титул не использовался другими отцами Собора ${ }^{8}$. Тем самым нет никаких признаков того, что греческие отцы Халкидонского собора приняли решение о даровании Льву титула, однако, с другой стороны, очевидно, что именно папские легаты, имея точные инструкции, пытались продвигать его на Соборе 9 .

Другим аргументом против титула Григорий считает то, что его предшественник, папа Пелагий II (579-590), «отменял деяния [константинопольского] собора» [46, p. 329.11330.16], фактически утвердившего за патриархом титул «вселенского» $[9$, р. 204-205; 15, p. 114-115; 16, S. 366-367; 19, p. 603]. Другими словами, папа сохраняет веру в то, что римский понтифик может своим указом отменить поместный собор другой церкви. Разбор подобных взглядов Григория на свой статус в Церкви заслуживает специального рассмотрения.

Церковно-политические и догматические аргументы. Папа Григорий считает, что претензия константинопольского патриарха на титул «вселенский» нарушает церковный мир и единство, причем «возникает прекословие всем вообще разлитой благодати» [46, p. 330.37-39]. Григорию кажется, что этим тяготится не только Римская церковь, но «воз- дыхают все [Церкви], хотя сказать ничего и не пытаются» [46, p. 317.75-77]. Императора он убеждает, что не стремится отплатить Иоанну за какую-либо личную обиду и защищает не «свое дело», но «дело всемогущего Бога и дело Вселенской Церкви» [46, p. 309.59-310.61].

Догматическое возражение Григория заключается в том, что у Вселенской церкви (universalis ecclesia) есть только один глава Христос, а христиане являются членами церкви под этой главой [46, p. 332.80-82]. В принятии же титула «вселенский» (universalis) Григорий наблюдает попытку патриарха стать главой Вселенской церкви вместо Христа [46, p. $331.45-55]^{10}$.

Принятие наименования «вселенский» ставит константинопольского патриарха выше всех остальных епископов, и честь (honor) последних тем самым «похищается», «уничтожается» [46, p. 310.74-76, 79-81], «попирается ногами» Иоанна [46, p. 331.65-67]. Григорий говорит, что титул подразумевает едва ли не отмену епископской благодати всех остальных епископов: «Брат мой и соепископ один стремится называться епископом» [20, p. 36-43; 46, p. 316.47-48]. По мысли Григория, возникающие на этой почве распри среди епископов тотчас прекратятся, если патриарх откажется от титула [46, p. 310.89-91].

Главная опасность видится Григорию в том, что если епископ, называющий себя «вселенским», обратится к ереси, то вместе с ним в ересь впадет и вся Вселенская церковь [46, p. 310.71-74]. Угроза этого тем выше, что на протяжении истории константинопольской церкви многие ее епископы становились еретиками и даже ересиархами: «И конечно, нам известно, что многие епископы (sacerdotes) впали в пучину константинопольской ереси, став не только еретиками, но даже ересиархами! Оттуда, конечно же, Несторий, который, считая, что посредник между Богом и людьми Иисус Христос был двумя лицами, поскольку не верил, что Бог мог стать человеком, дошел до иудейского вероломства. Оттуда Македоний, который отрицал, что Святой Дух единосущен Отцу и Сыну. Итак, если в сей Церкви кто-нибудь присвоит себе это наименование - что он, согласно мнению всех добрых [людей], и сделал - то, стало быть, и вся Церковь (universa ergo ecclesia) - чего да 


\section{ВИЗАНТИЙСКОЕ ПРАВОСЛАВИЕ}

не будет! - отпадет от своего положения, когда падет тот, кто называется «вселенским». Но да удалится от христианских сердец это богохульное наименование, в котором уничтожается честь всех священников, будучи безумно похищаема (arrogatur) одним» [9, p. 207; 19 , p. $608 ; 46$, p. $310.65-76]^{11}$.

Политические аргументы. Одним из лейтмотивов писем императору и императрице, как уже было сказано выше, является опасность для государства, которую представляют собой нестроения в Церкви, вызванные принятием титула. Григорий в красках описывает контраст между бедственным военнополитическим положением империи на границах и несоответствующим этому поведением патриарха, который вместо «домогательства тщеславных званий» должен был бы «плача лежать на полу и в пепле» [46, p. 309.53-58].

Император заверяется в том, что его вмешательство принесет «облегчение государству» и «долголетие царствования» [46, p. 309.35-37]. То же обещание - в письме императрице: «Итак, Ваше благочестие, которое вместе с тишайшим государем всемогущий Бог поставил править всем миром... сколь более верно послужит Творцу всех во исполнение истины, столь более надежно будет господствовать оно во врученном ему мире» [46, p. 315.20-25].

По мнению папы, поведение патриарха унижает не только достоинство священников, но и самой императорской власти: «Следует обуздать того, кто наносит оскорбление Вселенской Церкви, кто надмевается сердцем, кто стремится радоваться исключительному наименованию, кто частным обозначением даже ставит себя превыше достоинства Вашей власти (honori quoque vestri imperii)!» [46, p. 310.86-89]. Оно «оскверняет времена» правления Маврикия [46, p. 316.54-56].

Григорий, со своей стороны, показывает, что император имеет силу воспрепятствовать возвышению патриарха [46, p. 337.10$11,15-17]$, и, более того, императорская власть над патриархом превышает власть церковных канонов: «Тому, кто пренебрегает выказывать послушание каноническим наставлениям, следует более склоняться к наставлению благочестивейших государей» [46, p. 310.84-85].
В церковных нестроениях, как уже было сказано, Григорий видит корень тех бедствий, которые империя вообще и Италия в частности были вынуждены терпеть от вторжений варваров. Он пишет императору: «Вот все в областях Европы предано варварскому праву (iuri barbarorum): разрушены города, разорены крепости, обезлюдели провинции. Не населяет землю никто из правоверных (cultor): каждодневно свирепствуют и господствуют в смерти верных идолопоклонники. А священники, которые должны были, плача, лежать на полу и в пепле, домогаются себе тщеславных званий и похваляются неслыханными (novis) и нечестивыми (profanis) именами!» [46, p. 309.53-58].

В письмах августе и патриарху Григорий описывает и свое собственное сложное положение. Так, послание Иоанну Григорий заканчивает на весьма минорной ноте: «я, окруженный столь многими бедствиями, сдавлен мечами варваров (barbarorum gladiis premor), так что мне не только много рассуждать, а и вздохнуть едва ли возможно» [46, p. 336.211337.212-213].

Пастырские аргументы. Наименование епископа «вселенским», по мнению Григория, противоречит задаче священнического служения по научению паствы смирению [46, p. 330.31-36, 333.120-122]. Он опасается того, что из-за титула могут «оскверниться многие» [46, p. 336.189-190], поскольку он приводит к соблазнам: «[Братство Ваше] попыталось присвоить себе новоявленное наименование, отчего сердца многих братьев могли бы войти в соблазн» [46, p. 329.4-6].

Аскетические аргументы. Наиболее полно аскетические аргументы представлены в письме патриарху Иоанну. Ф. Дворник считал, что именно «аскетический характер [папы Григория]» послужил основной причиной его возражений против титула «вселенский» $[25, \text { p. } 80-81]^{12}$. По его мнению, Григорий не имел никакой иной цели, кроме как только преподать Иоанну нравственное поучение и предупредить его от излишней гордости. Косвенное подтверждение этому Дворник видит в том, что восточные патриархи относились к титулу «вселенский» спокойнее и воспринимали его «либо как пустую формулу, либо как выражение прав, предоставленных Кон- 
стантинополю Халкидонским собором» [25, p. 81] (cp. [19, p. 609]).

Как было сказано выше, титул сам по себе вызывал у папы Григория отторжение как «неслыханный и нечестивый» [46, p. 309.58], «гордый и глупый» [46, p. 330.41], «негодный», «надменный», «извращенный», как средство «похвалиться» и «казаться более знатным (digniores)» [46, p. 315.19-20]. Однако его принятие патриархом является для папы достаточной причиной подозревать того в гордыне: «Но уж не знаю, из-за какого дерзновения или какого надмения [братство Ваше] попыталось присвоить себе новоявленное наименование» [46, p. 329.4-6]. Он указывает на прежнюю скромность патриарха Иоанна [46, p. 332.74-75], на то, что раньше тот и сам не стремился к епископству [46, p. 329.6-7] и считал себя недостойным епископского сана [46, p. 329.9-11].

Письмо к патриарху содержит 25 ветхозаветных и новозаветных цитат, призванных напомнить ему о смирении (Ис. 66:2; Мф. 5:3, 11:29, 20:27), богопротивности гордыни (Притч. 16:5; Лк. 14:11; Иак. 4:6), необходимости удалиться от льстецов (Лк. 9:60; Пс. 69:4, 140:5) и близости последнего суда (1 Ин. 2:18) [19, p. 608-609]. Поведение Иоанна в деле с титулом неоднократно сравнивается с библейскими описаниями сатаны: «Кто, спрашиваю я, в столь извращенном наименовании берется за образец как не тот, кто, презрев легионы ангелов, поставленных товарищески вместе с ним, попытался вырваться к вершине уникальности, чтобы и никому не подчиняться, и в одиночестве казаться предстоящим всем? Кто также сказал: Взойду на небо, выле звезд небесных вознесу престол мой и сяду на горе завета, по бокам севера; взойду выше высоты облаков, буду подобен Всевышнему» [46, p. 331.55-62]. К образам гордыни, свойственной сатане и антихристу, которой Иоанн Константинопольский якобы подражает, Григорий прибегает в своих посланиях довольно часто [46, p. 316.46-48, 331.55-62, 331.64-332.72, 332.74-79, 334.144-146].

Папа предупреждает Иоанна, что, если тот не смирится, его гордость станет предметом рассмотрения «высших судей» [46, p. 336.190-192]. Однако если он откажется от титула, то сможет даже духовно возрасти и преуспеть [46, p. 330.39-331.43].
Практические меры папы против титула. Папа Григорий не ограничивается увещаниями против титула, но принимает и практические действия. Он запрещает своему апокрисиарию служить мессу вместе с патриархом [46, р. 338.32-33] и, по видимости, угрожает Иоанну каноническим разбирательством либо прещением в случае, если тот не откажется от титула: «Если ты не пожелаешь, я запретил ему (диакону Сабиниану, респонсалию папы в Константинополе - A.M.) справлять с Вашим братством служения месс, чтобы прежде с неким уважением ко стыду подтолкнуть святость Вашу, а затем, если отвратительное и нечестивое надмение не сможет смущенно исправиться, тогда уже прибегать к тому, что есть строгое и каноническое» [46, p. 330.22-27, 336.202-203] ${ }^{13}$.

Результаты. При общем сходстве посланий императору, императрице и Константинопольскому патриарху между ними наблюдаются значительные различия.

Тезисно укажем на аргументы, содержащиеся только в письме императору: титул противоречит Евангелию и церковным канонам; в случае падения «вселенского» патриарха в ересь вместе с ним падет и вся Церковь - тем вероятнее, что константинопольские епископы зачастую становились ересиархами.

В письме императрице акцент сделан на необходимости восстановить справедливость, поддержав позицию Римской церкви и тем самым снискав благоволение апостола Петра.

Аргументы, свойственные только письму патриарху: предыдущий папа, Пелагий II, отменил решения константинопольского собоpa, признавшего титул; догматический аргумент: Христос есть глава Церкви, а все остальные христиане суть ее члены; принятие же титула - это попытка занять место Христа; аскетические аргументы: ранее патриарх Иоанн был скромнее; ему необходимо подражать смирению Христа, иначе он подвергнется «высшему суду»; пастырские аргументы: по причине титула многие могут соблазниться, епископ жепризван учить смирению. Только в письме патриарху есть предупреждение о том, что в случае сохранения титула папа Григорий будет вынужден «призвать Церковь».

Общим для всех трех писем является резко-негативное отношение папы Григория к ти- 


\section{ВИЗАНТИЙСКОЕ ПРАВОСЛАВИЕ}

тулу «вселенский». Совпадает и основная цель посланий - принудить патриарха Иоанна отказаться от титула. Различается мотивация, по которой адресат должен исполнить просьбу папы Григория: в письме императору акцент сделан на унижении императорской власти по причине принятия патриархом титула и на благополучии государства в случае отказа от него; в письме императрице к этому добавляется благополучие семьи и пример родителей; в письме к патриарху папа Григорий преимущественно взывает к его совести и объясняет титул как лесть со стороны патриаршего окружения.

Только 2 аргумента против титула являются общими для всех трех посланий: нарушенный церковный мир и попрание чести всех остальных епископов. Неудивительно также и то, что во всех посланиях используются библейские цитаты; но если в письме императору их 5, а в письме императрице 3 , то патриарха Иоанна папа Григорий старается убедить с помощью 25 библейских цитат.

Для писем императору и императрице общим является только мотив унижения императорской власти и нарушения мира в государстве из-за церковных нестроений.

Сходство писем императору и патриарху заключается в апелляции к церковной традиции: обоим папа Григорий приводит в пример апостола Петра и папу Льва, которые не принимали титул «вселенский». Также в этих письмах папа Григорий говорит о практической мере против титула: о запрете своему апокрисиарию диакону Сабиниану сослужить патриарху Иоанну.

Общим для писем императрице и патриарху является и отрицательный пример антихриста - при этом в письме патриарху этот прием используется 4 раза. В письме императору одна из библейских цитат намекает на то, что титул делает патриарха богопротивником (Иак. 4:6) [46, p. 311.115-116], но нет прямых указаний на антихриста.

Исходя из проведенного анализа, позволим себе сделать вывод, что аргументация, с которой папа Григорий выступает против титула «вселенский», представляется тщательно выверенной в случае каждого послания. С учетом сложных условий - таких как противостояние лангобардам - конфликт по поводу поставления епископа Салоны, о котором папа Григорий пространно говорит в письме императрице, и общий недостаток времени - очевидно, что вопрос о титуле «вселенский» имел для Григория высокую важность. Следует сделать предположение, что значимость этого вопроса была обусловлена для Григория его восприятием особого положения и роли Римской кафедры по отношению к другим Церквам.

\section{ПРИМЕЧАНИЯ}

${ }^{1}$ О церковно-политической ситуации в Риме в это время см.: [16, S. 403-408; 19, p. 606-607; 21, p. 242-294; 37, p. 97-111;39, S. 279-306].

${ }^{2}$ Следует отметить, что каких-либо иных источников, помимо писем самого папы Григория, которые бы могли пролить свет на этот спор, не сохранилось.

${ }^{3}$ Пространное цитирование преимущественно одного из этих писем, обращенного императору, встречается в старых работах Ф. Успенского [6, c. 210-214] и в еще большей степени Ф.М. Даддена [22, p. 209-217]. Впрочем, аналитическим подход этих исследователей назвать невозможно. К примеру, Дадден настроен в отношении Григория апологетически: он декларирует его полную правоту, а противоположную сторону (императора и Константинопольского патриарха) выставляет хитрыми и коварными противниками святого папы. Подход Успенского более нюансирован: он отмечает необоснованность действий Григория, однако не дает им четкой оценки. Весьма краткий пересказ писем к императору, императрице и патриарху приводит также Э.Х. Фишер: [28, S. 101-103].

${ }^{4}$ Об отношениях Григория с Маврикием и со светскими властями в целом см.: [6, с. 223-233; 9, p. $194-200 ; 15$, p. $103-114 ; 16$, S. 479-482; 18; 22 , p. 238-266;26, S. 195-222; 42, S. 937-941].

${ }^{5}$ Об истории этого титула: [4, с. 38-42; 6, c. $208-210 ; 11$, S. $63-65 ; 19$, p. 602-603, 616-619; 29 , S. 567-572; 36, p. 6-14; 47, p. 261-270; 50]. Зачастую в старой литературе использование этого титула безосновательно, хотя чаще и в виде предположения приписывается уже Акакию Константинопольскому (472-489): [9, p. 205; 29, p. 568-569]. С полной уверенностью, ссылаясь на Батиффоля, об использовании титула Акакием говорит Л. Брейе: [15, p. 115]. Акакий Константинопольский в католической историографии также выставляется виновником так называемой «Акакианской схизмы»: [1, с. 362; 2].

${ }^{6}$ В письме диакону Сабиниану Григорий утверждает, что это внушение со стороны императора стало результатом «хитрости» и «тщеславия (vanitas)» патриарха Иоанна [46, p. 337.17-338.21]. 
${ }^{7}$ Важность ссылки на ап. Петра как части аргументации Григория подчеркивают старые католические авторы: [9, p. 206-207; 22, p. 213-216]. В последующих письмах Григорий в полной мере разворачивает римскую «петринологию» как учение о превосходстве и главенстве римской кафедры: [19, р. 613-614].

${ }^{8}$ Случаи применения определения «вселенский» в связи с титулованием Римского папы на Халкидонском соборе проанализированы М.В. Грацианским: [3, с. 258-264]. Католические исследователи склонны пренебрегать этим обстоятельством. Сp., к примеру, [15, p. 115]. Дж. Демакопулос, комментируя это высказывания Григория, совершенно неуместно, по нашему мнению, сравнивает позицию Григория с позицией папы Льва относительно 28-го правила Халкидонского собора. Для него остается неизвестной официальная позиция римских легатов, называющих папу Льва «епископом Вселенской Церкви города Рима»: [19, р. 609-610]. Между тем, ср. [29, S. 581-584].

${ }_{9}^{9}$ Ф. Успенский утверждал, что папа Григорий, говоря о даровании титула папе Льву I, стремился обосновать этим свое право называться «вселенским». См.: [6, с. 208]. Однако это не следует ни из письма императору, ни из других рассматриваемых нами писем. В этих письмах папа Григорий критикует как использование титула константинопольским патриархом, так и собственно сам титул. Сомнительно, чтобы он стал это делать, если бы предполагал усвоить титул самому себе.

${ }^{10} \mathrm{O}$ значительном различии коннотаций греческого оíкоv $\mu \varepsilon v ı$ ќ́ и латинского universalis см.: [19, p. 616-619; 47, p. 261-270].

${ }^{11}$ Насколько мы можем видеть, исследователями не отмечается тот факт, что этот антиконстантинопольский аргумент - а именно, что Константинопольские патриархи часто впадали в ересь, - был изобретен Григорием и впоследствии использовался папами вплоть до событий, приведших к окончательному расколу в 1054 г. В частности, к нему прибегает фактический автор этого раскола папа Лев IX (1049-1054): [7, p. 69-70]. Cp. [19, p. 610-611].

${ }^{12}$ О Григории как аскете: [16, S. 340-344].

${ }^{13} \Phi$. Успенский усматривает нерешительность папы Григория в том, что тот не принимает более существенных мер, в частности, воздерживается от разрыва евхаристического общения с константинопольским патриархом: [6, с. 216].

\section{СПИСОК ЛИТЕРАТУРЫ}

1. Грацианский, М. В. Акакианская схизма / М. В. Грацианский // Православная энциклопе- дия. Т. 1. - М. : ЦНЦ «Православная энциклопедия», 2000. $-362 \mathrm{c}$.

2. Грацианский, М. В. «Акакианская» или все же «феликианская» схизма? Проблема обоснованности одного историографического клише / М. В. Грацианский // Византийский временник. 2016. - T. 100. - С. 44-63.

3. Грацианский, М. В. Четвертый Вселенский собор и проблема первенства римского епископа / М. В. Грацианский // Вестник Волгоградского государственного университета. Серия 4, История. Регионоведение. Международные отношения. 2019. - T. 24, № 6. - C. 255-271. - DOI: https://doi.org/ 10.15688/jvolsu4.2019.6.20.

4. Кузенков, П. В. Канонический статус Константинополя и его интерпретация в Византии / П. В. Кузенков // Вестник Православного СвятоТихоновского гуманитарного университета. Серия I : Богословие. Философия. - 2014. - Вып. 3 (53). C. $25-51$.

5. Попов, И. Н. Иоанн IV Постник, патриарх Константинопольский / И. Н. Попов, К. А. Максимович // Православная энциклопедия. Т. 23. - М. : ЦНЦ «Православная энциклопедия», 2010. - С. 481-483.

6. Успенский, Ф. Церковно-политическая деятельность папы Григория I Двоеслова / Ф. Успенский. - Казань : Типо-литография Императорского Университета, 1901.-254, XIV c.

7. Acta et scripta quae de controversiis ecclesiae Graecae et Latinae saec. XI composita extant / ed. C. Will. - Leipzig; Marburg : N.G. Elwert, 1861.-X, $272 \mathrm{p}$.

8. Aigrain, R. San Gregorio Magno. La sua politica italiana / R. Aigrain // San Gregorio Magno, gli stati barbarici e la conquista araba (590-757) / L. Bréhier, R. Aigrain. - Torino : Editrice S.A.I.E., 1971. - P. 51101. - (Storia della Chiesa dalle origini al nostri giorni ; vol. 5).

9. Batiffol, P. Saint Grégoire le Grand / P. Batiffol.Paris : Librairie Lecoffre, 1928. - 233 p.

10. Baus, K. The Papacy between Byzantium and the German Kingdoms from Hilary (461-468) to Serguis I (687-701) // History of the Church. Vol. 2 / ed. by H. Jedin, J. Dolan. - New York : The Seabury Press, 1980. - P. 614-636.

11. Beck, H.-G. Kirche und theologische Literatur im byzantinischen Reich / H.-G. Beck. - München : C.H. Beck'sche Verlagsbuchhandlung, 1959. - xvi, $835 \mathrm{~S}$.

12. Bertolini, O. Roma di fronte a Bisanzio e ai Longobardi / O. Bertolini. - Bologna : Licinio Cappelli, 1941. $-886 \mathrm{p}$.

13. Bertolini, O. Roma ei Longobardi / O. Bertolini. Città di Castello : Istituto di studi Romani, 1972. - 150 p.

14. Booth, Ph. Gregory and the Greek East / Ph. Booth // A Companion to Gregory the Great / ed. 
by B. Neil, M. Dal Santo. - Leiden ; Boston : Brill, 2013. - P. 109-131.

15. Bréhier, L. Le relazioni fra Roma e Costantinopoli dall'elezione di Gregorio Magno alla caduta di Foca (590-610) / L. Bréhier // Bréhier, L. San Gregorio Magno, gli stati barbarici e la conquista araba (590-757)/ L. Bréhier, R. Aigrain. - Torino : Editrice S.A.I.E., 1971. - P. 103-129. - (Storia della Chiesa dalle origini al nostri giorni ; vol. 5).

16. Caspar, E. Geschichte des Papsttums von den Anfängen bis zur Höhe der Weltherrschaft. Bd. 2 / E. Caspar. - Tübingen : Verlag von J. C. B. Mohr (Paul Siebeck), 1933. - xv, 633 S.

17. Chadwick, H. The Church in Ancient Society: From Galilee to Gregory the Great / H. Chadwick. Oxford : Oxford University Press, 2001. - IX, 730 p.

18. Dal Santo, M. Gregory the Great, the Empire and the Emperor / M. Dal Santo // A Companion to Gregory the Great / ed. by B. Neil, M. Dal Santo. Leiden; Boston : Brill, 2013. - P. 57-81. - DOI: https:// doi.org/10.1163/9789004257764_004.

19. Demacopoulos, G. E. Gregory the Great and the Sixth-Century Dispute over the Ecumenical Title / G. E. Demacopoulos // Theological Studies. - 2009. Vol. 70. - P. 600-621. - DOI: https://doi.org/10.1177/ 004056390907000304.

20. Demacopoulos, G. E. Gregory the Great. Ascetic, Pastor, and First Man of Rome / G. E. Demacopoulos. Notre Dame, Indiana : University of Notre Dame Press, 2015. - viii, 236 p.

21. Dudden, F. M. Gregory the Great. His Place in History and Thought. Vol. 1 / F. M. Dudden. - London : Longmans, Green and Co, 1905. - xvii, 476 p.

22. Dudden, F. M. Gregory the Great. His Place in History and Thought. Vol. 2 / F. M. Dudden. - London : Longmans, Green and Co, 1905. - vi, 473 p.

23. Durliat, J. Grégoire I ${ }^{\mathrm{er}} / \mathrm{J}$. Durliat // Dictionnaire historique de la papauté / sous la direction de Ph. Levillain. - Paris : Fayard, 1994. - P. 736-740.

24. Durliat, J. Sabinien/J. Durliat// Dictionnaire historique de la papauté / sous la direction de Ph. Levillain. - Paris : Fayard, 1994. - P. 1495-1496.

25. Dvornik, F. Byzantium and the Roman Primacy / F. Dvornik. - New York : Fordham University Press, 1966. $-176 \mathrm{p}$.

26. Eich, P. Gregor der Große. Bischof von Rom zwischen Antike und Mittelalter / P. Eich. - Padeborn : Ferdinand Schöningh, 2016. - 311 S.

27. Ekonomou, A. J. Byzantine Rome and the Greek Popes. Eastern Influences on Rome and the Papacy from Gregory the Great to Zacharias, A.D. 590 752 / A. J. Ekonomou. - Lanham ; Boulder ; New York ; Toronto; Plymouth : Rowman \& Littlefield Publishers, INC, 2007. - IX, 347 p.

28. Fischer, E. H. Gregor der Große und Byzanz. Ein Beitrag zur Geschichte der päpstlichen Politik
/ E. H. Fischer // Zeitschrift der Savigny-Stiftung für Rechtsgeschichte. Kanonistische Abteilung, 1950. Bd. 36/1. - S. 15-144.

29. Gelzer, H. Der Streit über den Titel des ökumenischen Patriarchen / H. Gelzer // Jahrbücher für protestantische Theologie. - 1887. - Bd. 13. S. 549-584.

30. Grego, I. San Gregorio Magno e i Patriarchi d'Oriente / I. Grego // Studia Orientalia Christiana. 1988. - Vol. 21. - P. 267-293.

31. Haller, J. Das Papsttum. Idee und Wirklichkeit. Bd. 1 / J. Haller. - Stuttgart : Port Verlag, 1950. - 560 S.

32. Hartmann, L. Geschichte Italiens im Mittelalter. Bd. 1 / L. Hartmann. - Gotha : Friedrich Andreas Perthens, 1897. - ix, 409 S.

33. Jasper, D. Papal Letters in the Early Middle Ages / D. Jasper, H. Fuhrmann. - Washington DC : The Catholic University of America Press, 2001. - xiii, $225 \mathrm{p}$.

34. Jenal, G. Gregor I., der Große / G. Jenal // Das Papsttum. Bd. 1 / hrsg. von M. Greschat. - Stuttgart ; Berlin ; Köln ; Mainz : Verlag W. Kohlhammer, 1984. S. 83-99.-(Gestalten der Kirchengeschichte; Bd. 11).

35. Kelly, J. N. D. The Oxford Dictionary of Popes / J. N. D. Kelly. - Oxford ; New York : Oxford University Press, 1986. -347 p.

36. Laurent, V. Titre de patriarche oecuménique et la signature patriarcale / V. Laurent // Revue des études byzantines. - 1948. - T. 6. - P. 5-26.

37. Markus, R. A. Gregory the Great and His World / R. A. Markus. - Cambridge : Cambridge University Press, 1997. - xvi, 241 p.

38. McNally, R. E. Gregory the Great (590-604) and His Declining World / R. E. McNally// Archivium Historiae Pontificiae. - 1978. - Vol. 16. - P. 7-26.

39. Müller, B. Führung im Denken und Handeln Gregors des Grossen / B. Müller. - Tübingen : Mohr Siebeck, 2009. - x, 476 S.

40. Neil, B. The Papacy in the Age of Gregory the Great / B. Neil // A Companion to Gregory the Great / ed. by B. Neil, M. Dal Santo. - Leiden ; Boston : Brill, 2013. - P. 3-27. - DOI: https://doi.org/10.1163/ 9789004257764002.

41. Piccirillo, M. Gregorio Magno e le Province orientali di Palestina e Arabia / M. Piccirillo // Liber Annuus. - 2004. - Vol. 54. - P. 321-341.

42. Pietri, L. Gregor der Große und das wachsende Ansehen des Apostolischen Stuhls. Eine Untersuchung anhand seiner Briefe / L. Pietri, Ch. Fraisse-Coué // Der lateinische Westen und der byzantinische Osten (431-642) / hrsg. von L. Pietri. Freiburg; Basel ; Wien : Herder, 1998. - S. 890-961.(Die Geschichte des Christentums. Religion - PolitikKultur; Bd. 3).

43. Pohl, W. Gregorio Magno e il regno dei Longobardi / W. Pohl // Gregorio Magno, l'Impero e i 
«regna». Atti dell'incontro internazionale di studio dell'università degli studi di Salerno. Fisciano, 30 settembre - 1 ottobre 2004 / a cura di Claudioa Azzara. - Firenze : SISMEL. Edizioni del Galluzzo, 2008. - P. 15-28.

44. Pollard, R. M. A Cooperative Correspondence : The Letters of Gregory the Great / R. M. Pollard // A Companion to Gregory the Great / ed. by B. Neil, M. Dal Santo. - Leiden ; Boston : Brill, 2013. - P. 291312.-DOI: https://doi.org/10.1163/9789004257764_014.

45. Richards, J. The Popes and the Papacy in the Early Middle Ages, 476-752 / J. Richards. - New York : Routledge, 1979. - ix, 434 p.

46. S. Gregorii Magni Registrum epistularum. Vol. 1 / ed. D. Norberg. - Turholti : Brepols, 1982.-XII, 513 p. (Corpus Christianorum. Series Latina ; vol. 140).

47. Tuilier, A. Le sens de l'adjectif «oecuménique» dans la tradition patristique et dans la tradition byzantine / A. Tuilier // Nouvelle revue théologique. 1964. - Vol. 86/3. - P. 260-271.

48. Tuilier, A. Grégoire le Grand et le titre de patriarche œcuménique / A. Tuilier // Grégoire le Grand. Actes de colloque à Chantilly (Centre culturel Les Fontaines) 15-17 septembre 1982. - Paris : Éditions du Centre national de la recherche scientifique, 1986. P. 69-82.

49. Ullmann, W. Short History of the Papacy in the Middle Ages / W. Ullmann. - London ; New York : Routledge, 2003. - xvi, 278 p.

50. Vailhé, S. Le titre de patriarche oecuménique avant saint Grégoire le Grand / S. Vailhé // Échos d’Orient. - 1908. - T. 11, № 69. - P. 65-69.

51. Vailhé, S. Saint Grégoire le Grand et le titre de patriarche oecuménique/S. Vailhé // Échos d'Orient. 1908. - T. 11, № 70. - P. 161-171.

52. Western, J. The Papal Apocrisiarii in Constantinople during the Pontificate of Gregory I, 590-604 / J. Western // Journal of Ecclesiastical History. - 2015. - Vol. 64/4. - P. 697-714. - DOI: https:/ /doi.org/10.1017/S0022046915001621.

\section{REFERENCES}

1. Gratsianskiy M.V. Akakianskaya skhizma [Acacian Schism]. Pravoslavnaya entsiklopediya. T. 1 [The Orthodox Encyclopedia. Vol. 1]. Moscow, TsNTs «Pravoslavnaya entsiklopediya», 2000. 362 p.

2. Gratsianskiy M.V. «Akakianskaya» ili vse zhe «felikianskaya» skhizma? Problema obosnovannosti odnogo istoriograficheskogo klishe ["Acacian" or Rather "Felician" Schism? The Problem of Acceptability of a Historiographic Cliche]. Vizantiiskii vremennik, 2016, vol. 100, pp. 44-63.

3. Gratsianskiy M.V. Chetvertyy Vselenskiy sobor i problema pervenstva rimskogo episkopa [The
Fourth Ecumenical Council and the Issue of the Primacy of the Bishop of Rome]. Vestnik Volgogradskogo gosudarstvennogo universiteta. Seriya 4. Istoriya. Regionovedenie. Mezhdunarodnye otnosheniya [Science Journal of Volgograd State University. History. Area Studies. International Relations], 2019, vol. 24, no. 6, pp. 255-271. DOI: https:// doi.org/10.15688/jvolsu4.2019.6.20.

4. Kuzenkov P.V. Kanonicheskiy status Konstantinopolya i ego interpretatsiya v Vizantii [The Canonical Status of Constantinople and Its Interpretation in Byzantium]. Vestnik Pravoslavnogo SvyatoTikhonovskogo gumanitarnogo universiteta. Seriya I: Bogoslovie. Filosofia [St. Tikhon's University Review. Theology. Philosophy], 2014, iss. 3 (53), pp. 25-51.

5. Popov I.N., Maksimovich K.A. Ioann IV Postnik, patriarkh Konstantinopolskiy [John IV the Faster, Patriarch of Constantinople]. Pravoslavnaya entsiklopediya. T. 23 [The Orthodox Encyclopedia. Vol. 23]. Moscow, TsNTs «Pravoslavnaya entsiklopediya», 2010, pp. 481-483.

6. Uspenskiy F. Tserkovno-politicheskaya deyatelnost papy Grigoriya I Dvoeslova [ChurchPolitical Activity of Pope Gregory the Great]. Kazan, Tipo-litografiya Imperatorskogo Universiteta, 1901. 254, XIV p.

7. Will C., ed. Acta et scripta quae de controversiis ecclesiae Graecae et Latinae saec. XI composita extant. Leipzig, Marburg, N.G. Elwert, 1861. X, $272 \mathrm{p}$.

8. Aigrain R. San Gregorio Magno. La sua politica italiana. San Gregorio Magno, gli stati barbarici e la conquista araba (590-757). Torino, Editrice S.A.I.E., 1971, pp. 51-101. (Storia della Chiesa dalle origini al nostri giorni, vol. 5).

9. Batiffol P. Saint Grégoire le Grand. Paris, Librairie Lecoffre, 1928. 233 p.

10. Baus K. The Papacy Between Byzantium and the German Kingdoms from Hilary (461-468) to Serguis I (687-701). History of the Church. Vol. 2. New York, The Seabury Press, 1980, pp. 614-636.

11. Beck H.-G. Kirche und theologische Literatur im byzantinischen Reich. München, C.H. Beck'sche Verlagsbuchhandlung, 1959. xvi, $835 \mathrm{~S}$.

12. Bertolini O. Roma di fronte a Bisanzio e ai Longobardi. Bologna, Licinio Cappelli, 1941. 886 p.

13. Bertolini O. Roma e i Longobardi. Città di Castello, Istituto di studi Romani, 1972. 150 p.

14. Booth Ph. Gregory and the Greek East. Neil B., Dal Santo M., eds. A Companion to Gregory the Great. Leiden, Boston, Brill, 2013, pp. 109-131.

15. Bréhier L. Le relazioni fra Roma e Costantinopoli dall'elezione di Gregorio Magno alla caduta di Foca (590-610). Bréhier L., Aigrain R. San Gregorio Magno, gli stati barbarici e la conquista araba (590-757). Torino, Editrice S.A.I.E., 1971, 
pp. 103-129. (Storia della Chiesa dalle origini al nostri giorni; vol. 5).

16. Caspar E. Geschichte des Papsttums von den Anfängen bis zur Höhe der Weltherrschaft. Bd. 2. Tübingen, Verlag von J. C. B. Mohr (Paul Siebeck), 1933. xv, $633 \mathrm{~S}$.

17. Chadwick H. The Church in Ancient Society: From Galilee to Gregory the Great. Oxford, Oxford University Press, 2001. IX, 730 p.

18. Dal Santo M. Gregory the Great, the Empire and the Emperor. Neil B., Dal Santo M., eds. A Companion to Gregory the Great. Leiden, Boston, Brill, 2013, pp. 57-81. DOI: https://doi.org/10.1163/ 9789004257764_004.

19. Demacopoulos G.E. Gregory the Great and the Sixth-Century Dispute over the Ecumenical Title. Theological Studies, 2009, vol. 70, pp. 600-621. DOI: https://doi.org/10.1177/004056390907000304.

20. Demacopoulos G.E. Gregory the Great. Ascetic, Pastor, and First Man of Rome. Notre Dame, Indiana, University of Notre Dame Press, 2015. viii, $236 \mathrm{p}$.

21. Dudden F.M. Gregory the Great. His Place in History and Thought. Vol. 1. London, Longmans, Green and Co, 1905. xvii, $476 \mathrm{p}$.

22. Dudden F.M. Gregory the Great. His Place in History and Thought. Vol. 2. London, Longmans, Green and Co, 1905. vi, $473 \mathrm{p}$.

23. Durliat J. Grégoire Ier. Ph. Levillain, ed. Dictionnaire historique de la papauté. Paris, Fayard, 1994, pp. 736-740.

24. Durliat J. Sabinien. Levillain Ph., ed. Dictionnaire historique de la papauté. Paris, Fayard, 1994, pp. 1495-1496.

25. Dvornik F. Byzantium and the Roman Primacy. New York, Fordham University Press, 1966. $176 \mathrm{p}$.

26. Eich P. Gregor der Große. Bischof von Rom zwischen Antike und Mittelalter. Padeborn, Ferdinand Schöningh, 2016.311 S.

27. Ekonomou A.J. Byzantine Rome and the Greek Popes. Eastern Influences on Rome and the Papacy from Gregory the Great to Zacharias, A.D. 590-752. Lanham, Boulder, New York, Toronto, Plymouth, Rowman \& Littlefield Publishers, INC, 2007. IX, $347 \mathrm{p}$.

28. Fischer E.H. Gregor der Große und Byzanz. Ein Beitrag zur Geschichte der päpstlichen Politik. Zeitschrift der Savigny-Stiftung für Rechtsgeschichte. Kanonistische Abteilung, 1950, Bd. 36/1, S. 15-144.

29. Gelzer H. Der Streit über den Titel des ökumenischen Patriarchen. Jahrbücher für protestantische Theologie, 1887, Bd. 13, S. 549-584.

30. Grego I. San Gregorio Magno e i Patriarchi d'Oriente. Studia Orientalia Christiana, 1988, vol. 21, pp. 267-293.
31. Haller J. Das Papsttum. Idee und Wirklichkeit. Bd. 1. Stuttgart, Port Verlag, 1950. $560 \mathrm{~S}$.

32. Hartmann L. Geschichte Italiens im Mittelalter. Bd. 1. Gotha, Friedrich Andreas Perthens, 1897. ix, 409S.

33. Jasper D., Fuhrmann H. Papal Letters in the Early Middle Ages. Washington DC, The Catholic University of America Press, 2001. xiii, 225 p.

34. Jenal G. Gregor I., der Große. Greschat M., hrsg. Das Papsttum. Bd. 1. Stuttgart, Berlin, Köln, Mainz, Verlag W. Kohlhammer, 1984, S. 83-99. (Gestalten der Kirchengeschichte; Bd. 11).

35. Kelly J.N.D. The Oxford Dictionary of Popes. Oxford, New York, Oxford University Press, 1986. 347 p.

36. Laurent V. Titre de patriarche oecuménique et la signature patriarcale. Revue des études byzantines, 1948, T. 6, pp. 5-26.

37. Markus R.A. Gregory the Great and His World. Cambridge, Cambridge University Press, 1997. xvi, 241 p.

38. McNally R.E. Gregory the Great (590-604) and His Declining World. Archivum Historiae Pontificiae, 1978, vol. 16, pp. 7-26.

39. Müller B. Führung im Denken und Handeln Gregors des Grossen. Tübingen, Mohr Siebeck, 2009. x, $476 \mathrm{~S}$.

40. Neil B. The Papacy in the Age of Gregory the Great. Neil B., Dal Santo M., eds. A Companion to Gregory the Great. Leiden, Boston, Brill, 2013, pp. 327. DOI: https://doi.org/10.1163/9789004257764_002.

41. Piccirillo M. Gregorio Magno e le Province orientali di Palestina e Arabia. Liber Annuus, 2004, vol. 54, pp. 321-341.

42. Pietri L., Fraisse-Coué Ch. Gregor der Große und das wachsende Ansehen des Apostolischen Stuhls. Eine Untersuchung anhand seiner Briefe. L. Pietri, hrsg. Der lateinische Westen und der byzantinische Osten (431-642). Freiburg, Basel, Wien, Herder, 1998, S. 890-961. (Die Geschichte des Christentums. Religion - Politik - Kultur; Bd. 3).

43. Pohl W. Gregorio Magno e il regno dei Longobardi. Azzara C., ed. Gregorio Magno, l'Impero $e i$ «regna». Atti dell'incontro internazionale di studio dell'università degli studi di Salerno. Fisciano, 30 settembre - 1 ottobre 2004. Firenze, SISMEL. Edizioni del Galluzzo, 2008, pp. 15-28.

44. Pollard R.M. A Cooperative Correspondence: The Letters of Gregory the Great. Neil B., Dal Santo M., eds. A Companion to Gregory the Great. Leiden, Boston, Brill, 2013, pp. 291-312. DOI: https://doi.org/ 10.1163/9789004257764 014.

45. Richards J. The Popes and the Papacy in the Early Middle Ages, 476-752. New York, Routledge, 1979. ix, $434 \mathrm{p}$.

46. Norberg D., ed. S. Gregorii Magni Registrum epistularum. Vol. 1. Turnhout, Brepols, 1982. xii, 513 p. (Corpus Christianorum. Series Latina; vol. 140). 
47. Tuilier A. Le sens de l'adjectif «oecuménique» dans la tradition patristique et dans la tradition byzantine. Nouvelle revue théologique, 1964, vol. 86/3, pp. 260-271.

48. Tuilier A. Grégoire le Grand et le titre de patriarche œcuménique. Grégoire le Grand. Actes de colloque à Chantilly (Centre culturel Les Fontaines) 15-17 septembre 1982. Paris, Éditions du Centre national de la recherche scientifique, 1986, pp. 69-82.

49. Ullmann W. Short History of the Papacy in the Middle Ages. London, New York, Routledge, 2003. xvi, $278 \mathrm{p}$.
50. Vailhé S. Le titre de patriarche oecuménique avant saint Grégoire le Grand. Échos d'Orient, 1908, T. 11 , no. 69 , pp. 65-69.

51. Vailhé S. Saint Grégoire le Grand et le titre de patriarche oecuménique. Échos d'Orient, 1908, T. 11, no. 70, pp. 161-171.

52. Western J. The Papal Apocrisiarii in Constantinople During the Pontificate of Gregory I, 590-604. Journal of Ecclesiastical History, 2015, vol. 64/4, pp. 697-714. DOI: https://doi.org/10.1017/ S0022046915001621.

\section{Information About the Author}

Aleksei V. Migalnikov, Junior Researcher, Ecclesiastical Institutions Research Laboratory, St. Tikhon's Orthodox University, Likhov Lane 6/1, Office 418, 127051 Moscow, Russian Federation, migalnikov1990@gmail.com, https://orcid.org/0000-0002-4119-8872

\section{Информация об авторе}

Алексей Владимирович Мигальников, младший научный сотрудник Лаборатории исследований церковных институций, Православный Свято-Тихоновский гуманитарный университет, Лихов пер., 1, стр. 1, 127051 г. Москва, Российская Федерация, migalnikov1990@gmail.com, https://orcid.org/0000-0002-4119-8872 